\title{
Issues in Uncovering Hidden Identities in Intercultural Training
}

\author{
Brent J. Lyons, Simon Fraser University, Canada
}

INTERCULTURAL TEACHERS considering exercises that delve into sensitive topics, such as religion, need to consider that such exercises can often lead students to make disclosure decisions and that disclosure decisions have important implications. Similar to sexual orientation and political affiliation, religious identity is concealable in that religion cannot be identified simply based on appearance, and thus religious students may face disclosure decisions about whether they should openly talk about or actively conceal their religious worldview. Some students may be hesitant to talk about their religion because of potential stigmatization, but other students may be compelled to talk about their religion to take advantage of benefits associated with expressing oneself in an authentic way. This predicament has been referred to as the "disclosure dilemma." The disclosure dilemma refers to how individuals with concealable stigmatized identities attempt to balance the risks and benefits of disclosure when making decisions about how, when and to whom to disclose their identity (Goffman, 1963). A decision process in the face of threat, disclosure dilemmas can involve high cognitive resources, time and effort (Kahneman, 2003). Disclosure dilemmas are a significant source of stress for members of stigmatized social groups (Jones \& King, in press). Intercultural teachers can do much to affect students' disclosure decisions by managing

Classroom pressures to disclose a potentially stigmatized identity can be threatening and, as such, students may engage in deliberate, effortful and cognitively taxing decision processes (Kahneman, 2003) about whether or not they want to disclose. Disclosure decisions usually result from weighing anticipated risks and benefits to disclosing a stigmatized identity (Goffman, 1963). Students who fear that openly expressing their religious worldview may make them susceptible to interpersonal derogation and discrimination may choose to conceal their religion. Students who anticipate that disclosure of their religion would allow them to authentically express themselves and share ideas in a safe environment may choose to disclose their religion. Although concealing may reduce the likelihood of derogation and discrimination, concealing is also costly for students because keeping a secret can be anxiety-provoking, potentially negatively affecting social relationships and school performance (Goffman, 1963). Further, openly expressing oneself reduces anxiety around keeping a secret and allows students to express themselves in line with their self-concept (Jones \& King, in press). In a recent cross-nation study conducted in the United States and South Korea ( Lyons et al., in press), Christian-identified employees were more likely to conceal their religion (and less likely to disclose) when they perceived higher risks to disclosure and when their organization was not open to diverse religious expression. They were more likely to disclose their religion (and less likely to conceal) if they perceived that the risks of disclosure disclosure decisions by managing the risks and benefits associated with disclosure within their classroom. were low and that their organization was open to diverse religious expression. The authors also found that concealing religion was related

the risks and benefits associated with disclosure within their classroom. However, before choosing to implement sensitive exercises teachers need to carefully consider the broader social context including aspects of their classroom, university and societal contexts that students are likely to share, as well as the potentially different subcultures of particular students. With the social context in mind, teachers also need to manage the social relations within their classroom, fostering a climate of openness, support and respect, while being careful not to inadvertently manipulate students into disclosing hidden identities. Without doing so, teachers risk furthering the anxiety and even potential harm of those students whose identities are being challenged. to negative outcomes for the employees, including higher turnover intentions and reduced job satisfaction and well-being, whereas the outcomes for disclosure were generally positive. As the results of Lyons and colleagues' suggest, disclosing religion has generally beneficial outcomes and concealing has generally negative outcomes. Findings like these that suggest the consequences of concealment and benefits of disclosure (also see research on the disclosure decisions of lesbian, gay and bisexual employees: Griffith \& Hebl, 2002; Ragins, Singh, \& Cornwell, 2007) might easily be over interpreted to support the view that teachers should focus their efforts on encouraging students to disclose hidden identities. 
Teachers, however, need to recognize differences in audience and context. The results of the above-mentioned research do not suggest that teachers should blindly encourage or expect disclosure from their students. The experiences of adult employees who are not being pressured to disclose a hidden identity may not generalize to the experiences of students. Further, teachers need to consider the broader social context of the classroom, university and cultural differences in communication before adopting activities that may lead to sensitive disclosure decisions. Classroom activities that challenge the religious worldview of students may induce conflict and, if the conflict is not managed properly, lead to derogation and discrimination of those whose views are being challenged. This conflict can occur inside the classroom itself where the teacher has an opportunity to intervene, but it can also occur outside the classroom. In such contexts, the risks of disclosure may override the benefits and students may decide to conceal their religion (Lyons et al., in press). Further, as noted earlier, concealing an identity is associated with several psychological, interpersonal and performance costs, and by implementing a disclosure exercise in a non-supportive environment teachers may indirectly exacerbate stigmatization. Sensitive exercises in unsupportive contexts may also inadvertently manipulate students into making quick decisions about disclosure rather than allowing them the time and possible need for advice from others in their subculture to make such decisions. As such, the "step on Jesus" exercise may be more appropriate for students at a Catholic university where students may be more open to discussing their religion because they anticipate support for their religious worldview. The same may not apply to the context of state universities like Florida Atlantic University (Peterson, 2014) where such support may not be assured and students may reasonably fear stigmatization.

The "step on Jesus" exercise draws attention to disclosure of religion as a hidden identity in the United States, but the Academy of International Business certainly needs to consider other hidden identities besides religion, such as sexual orientation (Griffith \& Hebl, 2002; Ragins, Singh, \& Cornwell, 2007), and other societal contexts besides the United States. Regarding other societal contexts, Lyons and colleagues (in press) found national differences between the United States and South Korea in tendencies to conceal and disclose religion. In the United States, where individuality and self-interests are valued, open disclosure of religion was more common than it was in South Korea. In South Korea, where the suppression of self-interest relative to collective goals is especially valued (Hofstede \& Minkov, 2012), concealing was more common than in the United States. This difference in national context suggests that in classrooms composed of students with diverse cultural backgrounds, teachers need to consider how communication norms about selfexpression can affect disclosure decisions. In such contexts, disclosure of religion and other stigmatized social identities may be more sensitive for some students (like the South Koreans) than for others (like the students from the United States).

Contexts where teachers may be unsure about the supportiveness of students'social context or cultural differences in communication norms about disclosure require special caution. It is ill advised in such contexts to implement exercises that could lead to disclosure decisions that students make hastily or that carry the potential for further stigmatization that students lack the skills or experience to accurately anticipate. Perhaps intercultural teachers could draw upon less sensitive and less culturally biased exercises that still challenge important attitudes, yet avoid stress associated with personal disclosure and concealment and also allow students to be authentic to their worldview. If other exercises are not as effective and teachers choose to adopt sensitive exercises, teachers need to foster classroom environments that are conducive to safe and supportive discussion among culturally diverse students. Managing risks and benefits of disclosure within the classroom will go a long way in ensuring the effectiveness of sensitive intercultural communication exercises.

\section{References}

Goffman, E. 1963. Stigma: Notes on the management of spoiled identity. New York: Simon and Schuster.

Griffith, K., \& Hebl, M. 2002. The disclosure dilemma for gay men and lesbians: "Coming out at work." Journal of Applied Psychology, 87: 1191-1199.

Jones, K. J., \& King, E. B. In press. Managing dynamic and concealable identities: A review and theoretical model. Journal of Management.

Kahneman, D. 2003. A perspective on judgment and choice: Mapping bounded rationality. American Psychologist, 58: 696-720.

Lyons, B. J., Wessel, J. L., Ghumman, S., Ryan, A. M., \& Kim, S. Y. In press. Applying models of employee identity management across cultures: Christianity in the United States and South Korea. Journal of Organizational Behavior.

Minkov, M., \& Hofstede, G. 2012. Hofstede's fifth dimension new evidence from the world value survey. Journal of Cross-Cultural Psychology, 44: 3-14.

Peterson, M. F. 2014. Stepping on cultural and religious assumptions. AIB Insights, this issue.

Ragins, B. R., Singh, R., \& Cornwell, J. M. 2007. Making the invisible visible: Fear and disclosure of sexual orientation at work. Journal of Applied Psychology, 92: 1103-1118.

Brent J. Lyons (Email: brent.j.lyons@gmail.com) is Assistant Professor of Management and Organization Studies at Beedie School of Business, Simon Fraser University, Burnaby, BC, Canada. He has published in the Journal of Organizational Behavior, Journal of Managerial Psychology, Journal of Occupational Health Psychology, Ethics \& Behavior, and authored chapters in several books and numerous conference papers. He earned his Ph.D. at Michigan State University, an M.A. in Organizational Psychology, at MSU, and a BSc(hons) with Distinction at Queen's University at Kingston, Ontario, Canada. 